\title{
Protective effect of apigenin against oxidative stress-induced damage in osteoblastic cells
}

\author{
WOON-WON JUNG
}

\begin{abstract}
Department of Biomedical Laboratory Science, College of Health Sciences, Cheongju University, Cheongju, Chungbuk 360-764, Republic of Korea
\end{abstract}

Received December 4, 2013; Accepted February 18, 2014

DOI: $10.3892 /$ ijmm.2014.1666

\begin{abstract}
Apigenin, a plant-derived flavonoid, was investigated to determine whether it could influence hydrogen peroxide $\left(\mathrm{H}_{2} \mathrm{O}_{2}\right)$-induced oxidative damage and cellular dysfunction in the MC3T3-E1 mouse osteoblastic cell line. In the present study, osteoblastic cells were treated with $\mathrm{H}_{2} \mathrm{O}_{2}$ in the presence or absence of apigenin. Cell viability, apoptosis, reactive oxygen species (ROS) production and mitochondrial membrane potential $(\Delta \Psi \mathrm{m})$ were subsequently examined. It was observed that $\mathrm{H}_{2} \mathrm{O}_{2}$ reduced cell survival and $\Delta \Psi \mathrm{m}$, while it markedly increased the intracellular levels of ROS and apoptosis. However, pretreatment of cells with apigenin attenuated all the $\mathrm{H}_{2} \mathrm{O}_{2}$-induced effects. The antioxidants, catalase and $\mathrm{N}$-acetyl-L-cysteine (NAC) also prevented $\mathrm{H}_{2} \mathrm{O}_{2}$-induced oxidative cell damage. In addition, treatment with apigenin resulted in a significant elevation of osteoblast differentiation genes including alkaline phosphatase (ALP), collagen, osteopontin (OPN), osteoprotegerin (OPG), bone sialoprotein (BSP), osterix (OSX) and osteocalcin (OC) and bone morphogenetic proteins (BMPs) genes (BMP2, BMP4 and BMP7). In the mechanistic studies of cell signaling by the antioxidative potential of apigenin, it was found that apigenin activated the $\mathrm{H}_{2} \mathrm{O}_{2}$-induced decreased expression of phosphatidylinositol 3'-kinase (PI3K), protein kinase B2 (AKT2) genes and extracellular signal-related kinase (EPK) 2, which are key regulators of survival-related signaling pathways. By contrast, there were no changes in the expression of nuclear facor- $\kappa \mathrm{B}(\mathrm{NF}-\kappa \mathrm{B})$ and c-Jun N-terminal kinase (JNK) gene exposed to $\mathrm{H}_{2} \mathrm{O}_{2}$ in the present study. Apigenin also upregulated the gene expression of antioxidant enzymes, superoxide dismutase (SOD) 1, SOD2 and glutathione peroxidase (GPx) 1. Taken together, these
\end{abstract}

Correspondence to: Professor Woon-Won Jung, Department of Biomedical Laboratory Science, College of Health Sciences, Cheongju University, 298 Daesung-ro, Sangdang-gu, Cheongju, Chungbuk 360-764, Republic of Korea

E-mail:woonun@gmail.com

Key words: apigenin, flavonoid, osteoblastic cells, hydrogen peroxide, oxidative stress, MC3T3-E1 cells results suggested that apigenin attenuated oxidative-induced cell damage in osteoblastic cells and may be useful for the treatment of oxidative-related bone disease.

\section{Introduction}

Oxidative stress results from a persistent imbalance between antioxidant defenses and the production of highly reactive oxygen species (ROS). Under extreme oxidative conditions, or if the antioxidant protective mechanisms of cells are compromised, cell injury and death occur (1). Oxidative stress has been known to cause the etiology of various degenerative diseases including osteoporosis, in which the level of oxidative stress markers is increased (2). Mounting evidence have linked oxidative stress to the pathogenesis of osteoporosis. Basu et al (3) reported that there was a biochemical link between increased oxidative stress and decreased bone mineral density (BMD) in elderly men and women. Maggio et al (2) found that there was a significant decrease of plasma antioxidant levels for elderly women with osteoporosis. Oxidative stress may lead to bone loss by promoting lipid peroxidation, lowering antioxidant enzymes (4), and promoting apoptosis of osteoblasts (5). Osteoblasts are important cells that are responsible for bone formation. Several studies have shown that free radicals and ROS can affect the growth and function of these cells. Oxidative stress induced by exogenous stimuli such as hydrogen peroxide $\left(\mathrm{H}_{2} \mathrm{O}_{2}\right)$ is able to inhibit bone cell differentiation of the MC3T3-E1 osteoblastic cell line (6). Mody et al (7) and Mogi et al (8) showed that osteoblasts produce ROS such as nitrogen oxide and $\mathrm{H}_{2} \mathrm{O}_{2}$ in response to inflammatory cytokines. ROS may initiate lipid peroxidation (9), reduce antioxidant enzymes (10) and induce osteoblast apoptosis (11), as well as adversely affect osteoblast numbers at the bone formation site, contributing to bone loss (12). Therefore, ROS is a critical target for the prevention of bone loss, and antioxidants may be considered as potential candidates for the treatment of osteoporosis.

Flavonoids are naturally occurring polyphenolic dietary compounds broadly found in fruits and vegetables, and constitute the largest class of nutraceuticals in our diet (13). Apigenin, a non-toxic and non-mutagenic flavone, is widely distributed in many fruits and vegetables such as parsley, onions, orange, tea, chamomile, and wheat sprouts and in some seasonings (14). Apigenin has diverse biological 
effects, including improvement of the cancer cell response to chemotherapy (15), tumorigenesis (16), modulating immune cell function (17), and anti-platelet activity (18). In addition, apigenin reduced neutrophil migration towards inflammatory microenvironments (19). Previously it was reported that apigenin increased the growth and differentiation of osteoblastic MC3T3-E1 cells and decreased the TNF- $\alpha$-induced production of IL-6 and NO in osteoblasts (20). Although it is known that the health beneficial and pharmacological effects of apigenin are due to its antioxidant activities, the molecular mechanisms behind its biological effects on bone metabolism have yet to be determined. Oxidative stress is involved in the modulation of the expression of transcription factors and cellular signaling, which may affect osteoblast function. In the present study, I aimed to investigate the effects of apigenin on oxidative stress-induced damage and cellular dysfunction in MC3T3-E1 osteoblastic cells.

\section{Materials and methods}

Reagents. Apigenin (purity $>95 \%$ ) was purchased from Sigma Chemical Co. (St. Louis, MO, USA). Apigenin was dissolved in dimethyl sulfoxide (DMSO) and then diluted with medium [final DMSO concentration $\leq 0.05 \%(\mathrm{v} / \mathrm{v})$ ]. All other reagents were from Sigma Chemical Co. unless otherwise stated.

Cell culture.MC3T3-E1 mouse osteoblastic cells were obtained from the American Type Culture Collection (Rockville, MD, USA). The cells were cultured in $\alpha$-modified minimal essential medium ( $\alpha$-MEM; Invitrogen, Carlsbad, CA, USA) supplemented with $10 \%$ fetal bovine serum (FBS; Sigma Chemical Co.), $100 \mu \mathrm{U} / \mathrm{ml}$ penicillin and $100 \mu \mathrm{g} / \mathrm{ml}$ streptomycin. The cultures were maintained at $37^{\circ} \mathrm{C}$ in a humidified $5 \% \mathrm{CO}_{2}$ atmosphere and subcultured by trypsinization with $0.05 \%$ trypsin-0.02\% EDTA in $\mathrm{Ca}^{2+}$ - and $\mathrm{Mg}^{2+}$-free Dulbecco's phosphate-buffered saline (DPBS) until they reached $\sim 70 \%$ confluence. For assessment of cell viability, apoptosis, ROS production and mitochondrial membrane potential $(\Delta \Psi \mathrm{m})$, the cells were plated in 24-well culture plates at a density of $2 \times 10^{4}$ cells/well. Two days after culture, the cells were treated with apigenin for $24 \mathrm{~h}$ in $\alpha$-MEM containing $0.5 \% \mathrm{FBS}$ at varying concentrations $(0.01-100 \mu \mathrm{M})$ The cells were also seeded in a 6 -well culture plate at a density of $1 \times 10^{5}$ cells/ well and treated with culture medium containing $10 \mathrm{mM}$ $\beta$-glycerophosphate and $50 \mu \mathrm{g} / \mathrm{ml}$ ascorbic acid to initiate in vitro mineralization as previously described (21). The cell culture medium was changed every 2 days. After 6 days, the cells were cultured in medium containing $\mathrm{H}_{2} \mathrm{O}_{2}$ and/or apigenin for 2 days and the gene expression were then measured.

Cell viability. Cell viability was determined in cells exposed to various concentrations $(0.01-500 \mu \mathrm{M})$ of $\mathrm{H}_{2} \mathrm{O}_{2}$ for $24 \mathrm{~h}$. Cell viability was determined via the reduction of 3-(4,5-dimethylthiazol-2yl)-2,5-diphenyl tetrazolium bromide (MTT) by NAD-dependent dehydrogenase activity to form a colored reaction product. MTT $(0.5 \mathrm{mg} / \mathrm{ml}$ in PBS) was added to each well, and the plates were incubated for an additional $2 \mathrm{~h}$. After the removal of solutions in the well, DMSO was added to dissolve formazan products, and the plates were agitated for $5 \mathrm{~min}$. The absorbance of each well was recorded on a Zenyth 3100 microplate spectrophotometer at $570 \mathrm{~nm}$ (Anthos Labtec Instruments, Salzburg, Austria).

Measurement of ROS. The fluorescent probe, chloromethyl2,7-dichlorodihydrofluorescein diacetate (DCFDA; Molecular Probes, Inc., Eugene, OR, USA), was used to measure intracellular ROS levels as previously described (22). MC3T3-E1 osteoblastic cells were cultured for $24 \mathrm{~h}$ in $\alpha$-MEM containing $0.5 \%$ FBS, rinsed twice with DPBS, and then treated with $10 \mu \mathrm{M}$ of DCFDA for $1 \mathrm{~h}$. The cells were then rinsed, scraped and their fluorescence was measured (excitation $485 \mathrm{~nm}$ and emission $515 \mathrm{~nm}$ ) using a Zenyth 3100 multimode detector (Anthos Labtec Instruments).

Apoptosis determination by ELISA.Apoptosis ELISA kit(Roche Molecular Biochemicals, Mannheim, Germany) was used to measure apoptosis according to the manufacturer's instructions. Briefly, the cells were seeded at a density of $2 \times 10^{4}$ cells in 24-well culture plates. The culture conditions used were the same as those described for the cell viability assay. Following incubation, the cells were lysed and the intact nuclei were pelleted by centrifugation. An aliquot of the supernatant was used as the antigen source for sandwich ELISA using a primary anti-histone monoclonal antibody that was bound to the streptavidin-coated wells of a microtiter plate. Subsequently, the cells were treated with a second anti-DNA monoclonal antibody coupled to peroxidase. Nucleosome levels were quantified by determining the amount of peroxidase retained in the immunocomplex. Peroxidase activity was determined photometrically at $405 \mathrm{~nm}$ using 2,2'-azino-di(3-ethylbenzthiazolin-sulfonate) (ABTS) as the substrate.

Determination of $\Delta \Psi m$. The $\Delta \Psi \mathrm{m}$ of cells was measured using a JC-1 (5,5',6,6'-tetrachloro-1,1',3,3'-tetraethylbenzimidazolylcarbocyanine iodide) $\Delta \Psi \mathrm{m}$ detection kit (Cayman Chemical Co., Ann Arbor, MI, USA). The cells were incubated with the $\Delta \Psi \mathrm{m}$-sensitive fluorescent dye JC-1 for $20 \mathrm{~min}$ at $37^{\circ} \mathrm{C}$, washed twice in DPBS, and then red fluorescence (excitation $550 \mathrm{~nm}$, emission $600 \mathrm{~nm}$ ) and green fluorescence (excitation $485 \mathrm{~nm}$, emission $535 \mathrm{~nm}$ ) were measured using a Zenyth 3100 multimode detector. Mitochondrial depolarization (i.e., loss of $\Delta \Psi \mathrm{m}$ ) indicated by a decrease in the red/green fluorescence ratio.

RNA extraction and gene expression by quantitative polymerase chain reaction ( $q R T-P C R)$ analysis. Total RNA was isolated from the cells using TRIzol reagent (Invitrogen). Following isolation, RNA integrity was assessed using an Agilent 2100 Bioanalyzer (Agilent Technologies, Inc., Palo Alto, CA, USA). cDNA was synthesized using the Transcriptor First Strand cDNA synthesis kit (Roche Diagnostics GmbH, Mannheim, Germany). All the procedures were carried out according to the manufacturer's instructions. RT-PCR was performed to verify the differential expression of selected genes using a Roche LightCycler 480 system (Roche Diagnostics $\mathrm{GmbH}$ ) and the TaqMan method using the Roche Universal Probe Library (UPL) kit. Relative gene expression was determined by employing the comparative CT method. Reactions were carried out in a total volume of $20 \mu \mathrm{l}$ of reaction mixture containing $10 \mu \mathrm{l}$ of $2 \mathrm{X}$ UPL Master mix, $1.0 \mu \mathrm{l}$ of 
Table I. Primer sequences used in this study.

\begin{tabular}{|c|c|c|c|}
\hline Genes & Accession no. & Forward primer & Reverse primer \\
\hline AKT1 & NM_009652.3 & 5'-TCG TGT GGC AGG ATG TGT AT-3' & 5'-ACC TGG TGT CAG TCT CAG AGG-3' \\
\hline AKT2 & NM_001110208.1 & 5'-CGA CCC AAC ACC TTT GTC A-3' & 5'-GAT AGC CCG CAT CCA CTC T-3' \\
\hline AKT3 & NM_011785.3 & 5'-TGG ACC ACT GTT ATA GAG AGA ACA TTT-3' & 5'-TGG ATA GCT TCC GTC CAC TC-3' \\
\hline ALP & NM_007431.2 & 5'-GGC CAG CTA CAC CAC AAC A-3' & 5'-CTG AGC GTT GGT GTT ATA TGT CTT-3' \\
\hline BMP2 & NM_007553.2 & 5'-GGT CAC AGA TAA GGC CAT TGC-3' & 5'-GCT TCC GCT GTT TGT GTT TG-3' \\
\hline BMP4 & NM_007554.2 & 5'-GAG GAG TTT CCA TCA CGA AGA-3' & 5'-GCT CTG CCG AGG AGA TCA-3' \\
\hline BMP7 & NM_007557.2 & 5'-CGA TAC CAC CAT CGG GAG TTC-3' & 5'-AAG GTC TCG TTG TCA AAT CGC-3' \\
\hline BSP & NM_008318.3 & 5'-GAA AAT GGA GAC GGC GAT AG-3' & 5'-CAT TGT TTT CCT CTT CGT TTG A-3' \\
\hline Collagen & NM_007742.3 & 5'-AGA CAT GTT CAG CTT TGT GGA C-3' & 5'-GCA GCT GAC TTC AGG GAT G-3' \\
\hline ERK1 & NM_011952.2 & 5'-TGG AAG CCA TGA GAG ATG TTT-3' & 5'-GCT CAG CTG CTG GCT TTT A-3' \\
\hline ERK2 & NM_011949.3 & 5'-CGT TCT GCA CCG TGA CCT-3' & 5'-TGA TCT GGA TCT GCA ACA CG-3' \\
\hline ERK5 & NM_011841.1 & 5'-TAC GGG GTG GTG TCT TCG-3' & 5'-AAA GCA TTA GGT ATC TTC TTG ATG G-3' \\
\hline GPx 1 & NM_008160.6 & 5'-GGT TTC CCG TGC AAT CAG T-3' & 5'-TCG GAC GTA CTT GAG GGA AT-3' \\
\hline GPx4 & NM_001037741.2 & 5'-TAA GAA CGG CTG CGT GGT-3' & 5'-GTA GGG GCA CAC ACT TGT AGG-3' \\
\hline HPRT & NM_013556.2 & 5'-TCC TCC TCA GAC CGC TTT T-3' & 5'-CCT GGT TCA TCA TCG CTA ATC-3' \\
\hline JNK & NM_016700.4 & 5'-GAA GCT CTC CAG CAC CCA TA-3' & 5'-TAA CTG CTT GTC CGG GAT CT-3' \\
\hline$N F-\kappa B$ & NM_008689.2 & 5'-CAC TGC TCA GGT CCA CTG TC-3' & 5'-CTG TCA CTA TCC CGG AGT TCA-3' \\
\hline OPG & NM_008764.3 & 5'-ATG AAC AAG TGG CTG TGC TG-3' & 5'-CAG TTT CTG GGT CAT AAT GCA A-3' \\
\hline OPN & NM_001204201.1 & 5'-TGA GAT TGG CAG TGA TTT GC-3' & 5'-ATC TGG GTG CAG GCT GTA AA-3' \\
\hline Osteocalcin & NM_031368.4 & 5'-CAC CAT GAG GAC CCT CTC TC-3' & 5'-TGG ACA TGA AGG CTT TGT CA-3' \\
\hline Osterix & NM_130458.3 & 5'-CTC CTG CAG GCA GTC CTC-3' & 5'-GGG AAG GGT GGG TAG TCA TT-3' \\
\hline PI3K & NM_020272.2 & 5'-TTT GGG AGA CTG AAT CTC TGG-3' & 5'-GTG GCA TCC TTT ACA ATC TCG-3' \\
\hline SOD1 & NM_011434.1 & 5'-CCA TCA GTA TGG GGA CAA TAC A-3' & 5'-GGT CTC CAA CAT GCC TCT CT-3' \\
\hline SOD2 & NM_013671.3 & 5'-GAC CCA TTG CAA GGA ACA A-3' & 5'-GTA GTA AGC GTG CTC CCA CAC-3' \\
\hline SOD3 & NM_011435.3 & 5'-GGG GAG GCA ACT CAG AGG-3' & 5'-TGG CTG AGG TTC TCT GCA C-3' \\
\hline
\end{tabular}

AKT, protein kinase B; ALP, alkaline phosphatase; BMP, bone morphogenetic protein; BSP, bone sialoprotein; ERK, extracellular signal-related kinase; GPx, glutathione peroxidase; HPRT, hypoxanthine guanine phosphoribosyltransferase; JNK, c-Jun N-terminal kinase; NF- $\kappa \mathrm{B}$, nuclear factor- $\kappa \mathrm{B}$; OPG, osteoprotegerin; OPN, osteopontin; PI3K, phosphatidylinositol 3'-kinase; SOD, superoxide dismutase.

$5^{\prime}$ primer $(10 \mathrm{pmol} / \mu \mathrm{l}), 1.0 \mu \mathrm{l}$ of $3^{\prime} \operatorname{primer}(10 \mathrm{pmol} / \mathrm{ml}), 0.2 \mu \mathrm{l}$ of UPL probe, $1.0 \mu \mathrm{l}$ of cDNA and $6.8 \mu \mathrm{l}$ of sterile water. The thermal cycling conditions for PCR were: initial denaturation for $10 \mathrm{~min}$ at $95^{\circ} \mathrm{C}$, followed by 40 cycles of $94^{\circ} \mathrm{C}$ for $10 \mathrm{sec}$ and $60^{\circ} \mathrm{C}$ for $30 \mathrm{sec}$. The primers summarized in Table I were designed using the Roche ProbeFinder assay tool. For RT-PCR analysis, duplicate PCRs were carried out for each cDNA. Negative controls (except templates) were included in the PCR reaction to ensure specific amplification. LightCycler 480 software version 1.2 (Roche Diagnostics $\mathrm{GmbH}$ ) was used for the analysis of the qPCR. The values obtained from each sample were normalized to hypoxanthine guanine phosphoribosyltransferase (HPRT) expression. The levels of each gene expression in all the experimental groups were compared to the expression levels of the control group.

Statistical analysis. Results are expressed as the means \pm standard deviation (SD). Statistical analysis was performed using one-way ANOVA with a subsequent Tukey's multiple comparison test. $\mathrm{P}<0.05$ was considered to indicate a statistically significant difference. Statistical analysis was performed using SAS software (SAS Institute, Inc., Cary, NC, USA).

\section{Results and Discussion}

The effects of apigenin on $\mathrm{H}_{2} \mathrm{O}_{2}$-induced oxidative cell damage and cellular dysfunction in MC3T3-E1 osteoblastic cells were investigated. The oxidizing capacity of $\mathrm{H}_{2} \mathrm{O}_{2}$ is extremely strong and is considered a highly expressed ROS. To evaluate the effect of $\mathrm{H}_{2} \mathrm{O}_{2}$ on MC3T3-E1 osteoblastic cell survival, cell viability was determined using the MTT assay. As shown in Fig. 1A, a dose-dependent decrease was observed in cell viability in cells exposed to various concentrations (0.01-500 $\mu \mathrm{M}$ ) of $\mathrm{H}_{2} \mathrm{O}_{2}$ for $24 \mathrm{~h}$. Based on the results of these cytotoxicity studies, I used $300 \mu \mathrm{M} \mathrm{H}_{2} \mathrm{O}_{2}$ in subsequent biochemical assays. At this concentration, $50 \%$ inhibition of cell viability occurred in $24 \mathrm{~h}$ under these experimental culture conditions. The antioxidants, catalase and N-acethylL-cystein (NAC), were used to investigate the mechanism of $\mathrm{H}_{2} \mathrm{O}_{2}$-induced cell damage. Pretreatment of cells with 50 units catalase or $10 \mathrm{mM}$ NAC almost completely reversed the $\mathrm{H}_{2} \mathrm{O}_{2}$ induced cytotoxicity (Fig. $1 \mathrm{~B}$ and $\mathrm{C}$ ). These findings suggest that the $\mathrm{H}_{2} \mathrm{O}_{2}$-induced cytotoxicity was most likely due to oxidative stress-induced effects.

To evaluate the effect of apigenin itself on MC3T3-E1 osteoblastic cell survival, cells were incubated in $\alpha$-MEM containing $0.5 \%$ FBS with increasing concentrations of apigenin $(0.01-100 \mu \mathrm{M})$ for $24 \mathrm{~h}$ and the cell viability was determined. Apigenin at $\leq 1 \mu \mathrm{M}$ concentrations had no effect on cell viability (Fig. 2A), while higher doses ( $\geq 10 \mu \mathrm{M})$ were cytotoxic. To determine whether apigenin had any effect on the $\mathrm{H}_{2} \mathrm{O}_{2}$-induced decrease in cell survival, the cells were preincubated with apigenin for $30 \mathrm{~min}$ and then cultured with $300 \mu \mathrm{M}$ $\mathrm{H}_{2} \mathrm{O}_{2}$ for $24 \mathrm{~h}$. Results of MTT assay showed that apigenin 
A
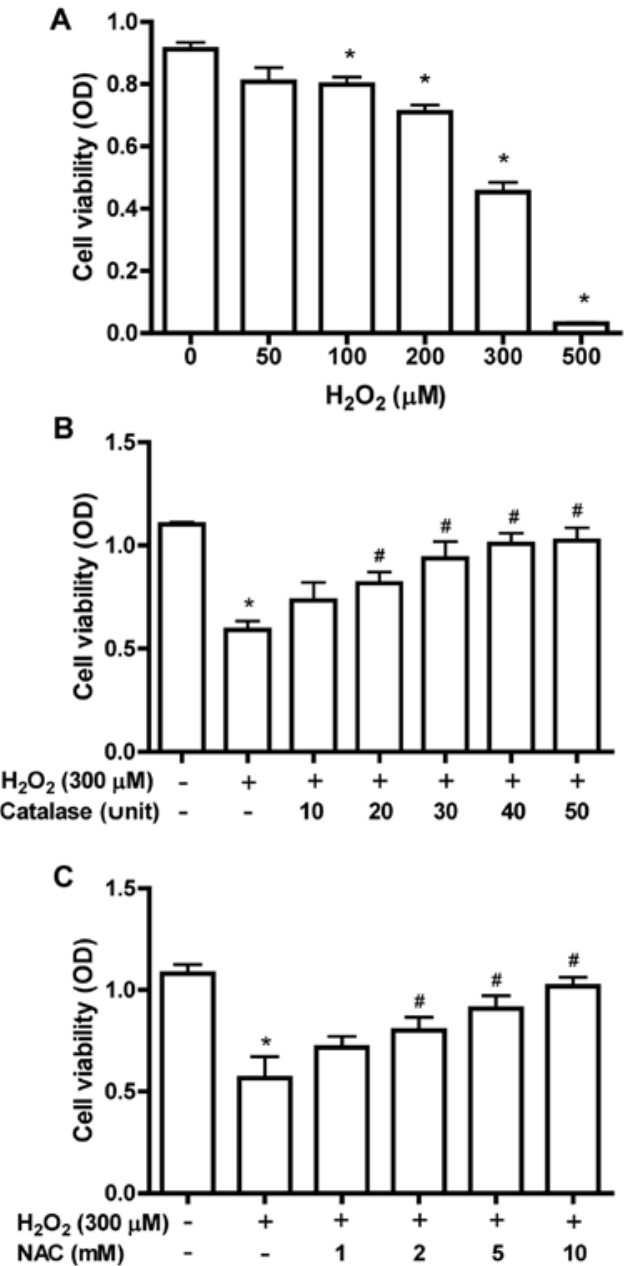

Figure 1. Cell viability in response to various concentrations of hydrogen peroxide $\left(\mathrm{H}_{2} \mathrm{O}_{2}\right)$ treatment. Osteoblast cells were cultured in $\alpha$-MEM containing $10 \%$ fetal bovine serum (FBS) at varying concentrations of cells and $\mathrm{H}_{2} \mathrm{O}_{2}$ for $48 \mathrm{~h}$. Cells were cultured in $\alpha$-MEM containing $0.5 \%$ FBS for $24 \mathrm{~h}$ Cell viability was determined by a 3-(4,5-dimethyl-thiazol-2yl)-2,5-diphenyl tetrazolium bromide (MTT) assay (A). The osteoblast cells were cultured in $\alpha$-MEM containing $10 \%$ FBS for $48 \mathrm{~h}$. Cells were cultured in $\alpha$-MEM containing $0.5 \% \mathrm{FBS}$ at varying concentrations of antioxidants, catalase (B) or N-acetyl-L-cysteine (NAC) (C) in the presence of $300 \mu \mathrm{M} \mathrm{H}_{2} \mathrm{O}_{2}$ for $24 \mathrm{~h}$. ${ }^{*} \mathrm{P}<0.05$ vs. untreated control, ${ }^{\#} \mathrm{p}<0.05$ vs. $\mathrm{H}_{2} \mathrm{O}_{2}$-treated cells.

(0.1 and $1 \mu \mathrm{M})$ partially reversed the $\mathrm{H}_{2} \mathrm{O}_{2}$-mediated reduction in cell viability (Fig. 2B). Therefore, I selected the highest non-toxic concentration of apigenin $(1 \mu \mathrm{M})$ for all subsequent cell culture experiments.

The oxidative stress caused by $\mathrm{H}_{2} \mathrm{O}_{2}$ in MC3T3-E1 osteoblastic cell was evaluated by measuring ROS generation and apoptosis. Oxidative stress may initiate a mitochondrial permeability transition event, which is an early mediator of cell apoptosis. When cells were treated with $300 \mu \mathrm{M} \mathrm{H}_{2} \mathrm{O}_{2}$, ROS generation and apoptosis increased, while $\Delta \Psi \mathrm{m}$ decreased. Treatment with apigenin $(1 \mu \mathrm{M})$ in the presence of $\mathrm{H}_{2} \mathrm{O}_{2}$ attenuated all the $\mathrm{H}_{2} \mathrm{O}_{2}$-induced effects (Fig. 3). I used the antioxidants, catalase and NAC, to investigate the effect of oxidative stress in the cells. Catalase and NAC prevented the $\mathrm{H}_{2} \mathrm{O}_{2}$-induced cell effects. These data are consistent with a previous study showing that the antioxidants protect MC3T3-E1 osteoblastic cells against oxidative stress as shown by a reduction in ROS generation and apoptosis (23).
A
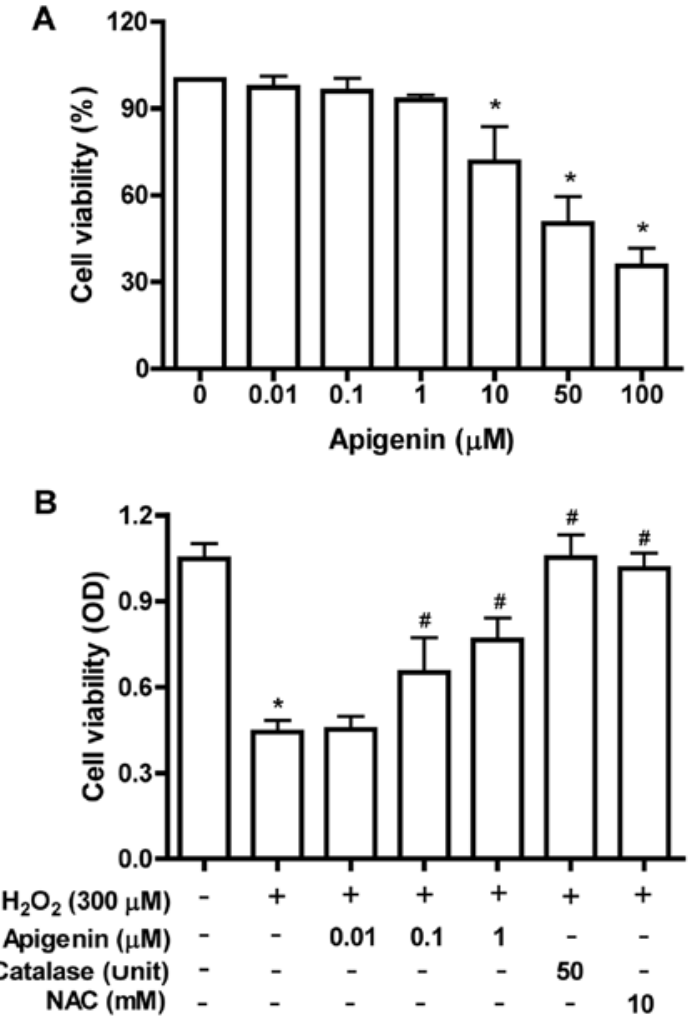

Figure 2. Effects of apigenin on cell viability. The osteoblast cells were cultured in $\alpha$-MEM containing $10 \%$ fetal bovine serum (FBS) for $48 \mathrm{~h}$. Cells were cultured in $\alpha$-MEM containing $0.5 \%$ FBS at varying concentrations of apigenin for $24 \mathrm{~h}$. Cell viability was determined using 3-(4,5-dimethylthiazol-2yl)-2,5-diphenyl tetrazolium bromide (MTT) assay (A). The osteoblast cells were cultured in $\alpha$-MEM containing $10 \% \mathrm{FBS}$ for $48 \mathrm{~h}$. Cells were cultured in $\alpha$-MEM containing $0.5 \%$ FBS at varying concentrations of apigenin, catalase (50 units) and N-acetyl-L-cysteine (NAC) (10 mM) in the presence of $300 \mu \mathrm{M}$ hydrogen peroxide $\left(\mathrm{H}_{2} \mathrm{O}_{2}\right)$ for $24 \mathrm{~h}$ (B). ${ }^{*} \mathrm{P}<0.05$ vs. untreated control, ${ }^{\#} \mathrm{p}<0.05$ vs. $\mathrm{H}_{2} \mathrm{O}_{2}$-treated cells.

These findings indicate that apigenin can function as an antioxidant and thereby protect MC3T3-E1 osteoblastic cells from $\mathrm{H}_{2} \mathrm{O}_{2}$-induced oxidative cell damage. JC-1 staining was used to assess $\Delta \Psi \mathrm{m}$, which is a marker of mitochondrial oxidative phosphorylation activity. A low JC-1 ratio indicates a low amount of the aggregated form of JC-1 in the mitochondria, which correlates with a high amount of ROS (24). Oxidative stress may initiate a mitochondrial permeability transition event, which is an early indication of the initiation of cellular apoptosis. This process is typically defined as a collapse in the electrochemical gradient across the mitochondrial membrane, as measured by the change in the mitochondrial $\Delta \Psi \mathrm{m}$ (25). Mitochondrial dysfunction is a consequence of oxidative damage caused by increased oxidant levels. In this study, the pretreatment of cells with apigenin attenuated a marked decrease in $\mathrm{H}_{2} \mathrm{O}_{2}$-induced $\Delta \Psi \mathrm{m}$ (Fig. $3 \mathrm{C}$ ). These results suggest that apigenin protects mitochondrial function as an antioxidant in osteoblastic cells.

MC3T3-E1 cells are the osteoblastic precursor cell line, which is the most frequently used to study osteoblast differentiation (26). Osteoblast differentiation is the primary event of bone formation. I analyzed the gene expression of a number of molecular markers of osteoblast differentiation. Bone alkaline phosphatase (ALP) is a glycoprotein localized 

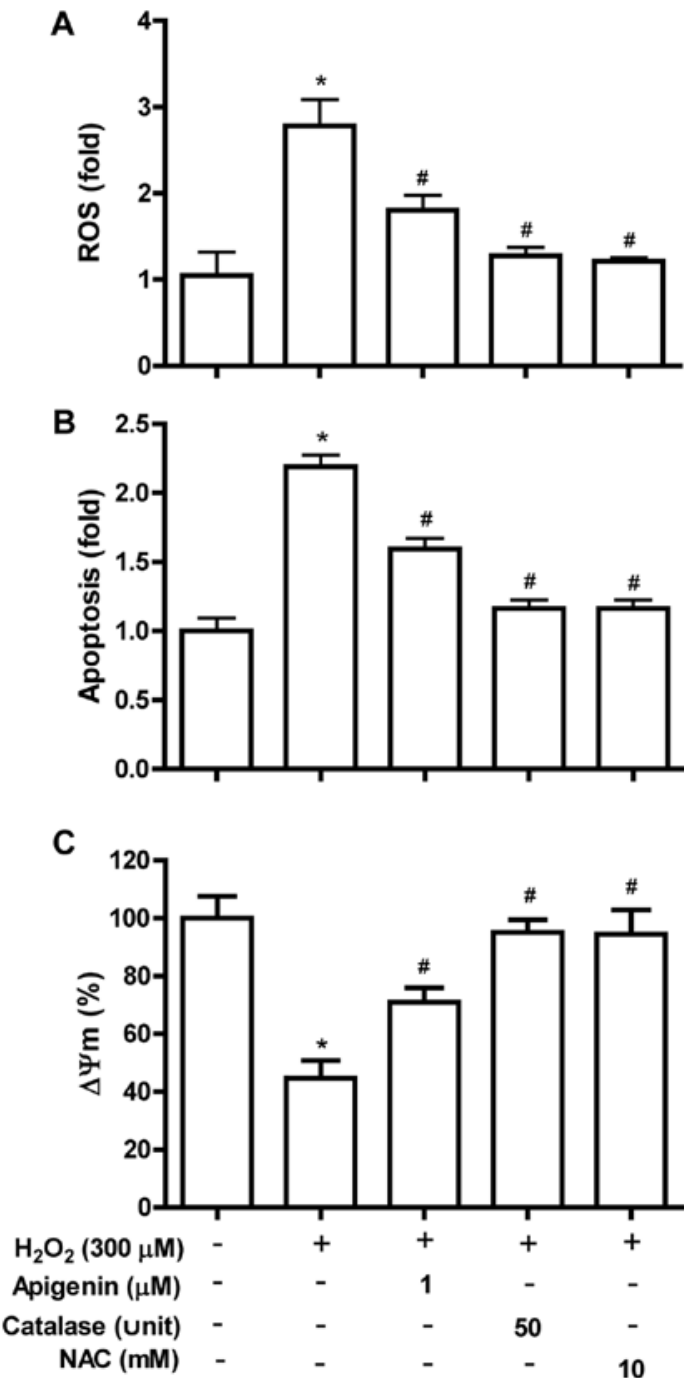

Figure 3. Apigenin inhibits hydrogen peroxide $\left(\mathrm{H}_{2} \mathrm{O}_{2}\right)$-induced reactive oxygen species (ROS) production, apoptosis and mitochondrial membrane potential $(\Delta \Psi \mathrm{m})$. The osteoblast cells were cultured in $\alpha$-MEM containing $10 \%$ fetal bovine serum (FBS) for $48 \mathrm{~h}$. Cells were cultured in $\alpha$-MEM containing $0.5 \%$ FBS with apigenin $(1 \mu \mathrm{M})$, catalase (50 units) and $\mathrm{N}$-acetylL-cysteine (NAC) $(10 \mathrm{mM})$ in the presence of $300 \mu \mathrm{M} \mathrm{H}_{2} \mathrm{O}_{2}$ for $24 \mathrm{~h}$. ROS production (A), apoptosis (B) and $\Delta \Psi \mathrm{m}(\mathrm{C}) .{ }^{*} \mathrm{P}<0.05$ vs. untreated control, ${ }^{\#} \mathrm{p}<0.05$ vs. $\mathrm{H}_{2} \mathrm{O}_{2}$-treated cells.

in the plasma membrane of osteoblastic cells, which is one of the osteoblastic phenotype markers (27). Alterations in ALP activity have been observed in osteoporosis and other metabolic bone diseases. Osteoblastic cells produce type I collagen, which is the most abundant protein in the bone matrix, serves an early marker of osteoblast differentiation, and is the major organic component of mineralized bone matrix (28). Osteopontin (OPN) is a major acidic phosphorylated glycoprotein secreted by osteoblasts and acts as a regulator of bone formation (29). Osteoprotegerin (OPG), produced by osteoblastic cells is one of the regulators of bone metabolism and inhibits bone resorption by regulating the function of osteoclast (30). Bone sialoprotein (BSP) functions in the initial mineralization of bone and could be crucial for osteoblast differentiation (31). The flavonoid kaempferol stimulates BSP gene transcription and new bone formation (29). The osterix (OSX) is a zinc finger-containing transcription factor that is essential for osteoblastic cell differentiation and bone homeostasis $(32,33)$. Thus, these molecular markers are important regulators of osteoblast function. In this study, cells were treated with $\mathrm{H}_{2} \mathrm{O}_{2}$ in the presence or absence of apigenin. Seven differentiation makers [(ALP, collagen, OPN, OPG, BSP, OSX and osteocalcin (OC)] were downregulated in response to the $\mathrm{H}_{2} \mathrm{O}_{2}$ induction. However, apigenin treatment partially inhibited the $\mathrm{H}_{2} \mathrm{O}_{2}$-induced downregulation of gene expression of differentiation markers (Fig. 4).

Bone morphogenetic proteins (BMPs) are known to be multifunctional growth factors. BMPs induce the formation of bone and cartilage. Osteoblastic cells are highly BMP-responsive and can complete the differentiation process in the cultures. BMPs stimulated ALP activities, collagen synthesis, parathyroid hormone $(\mathrm{PTH})$ responsiveness and $\mathrm{OC}$ production in osteoblastic cells $(34,35)$, suggesting that BMPs stimulate the differentiation function of osteoblastic cells. The present study demonstrated that $\mathrm{H}_{2} \mathrm{O}_{2}$ had a profound inhibitory effect on the gene expression of BMPs; however, when osteoblasts were treated with apigenin in the presence of $\mathrm{H}_{2} \mathrm{O}_{2}$, BMPs including BMP2, BMP4 and BMP7, were significantly increased (Fig. 5). It is suggested that apigenin exerts the differentiation function of osteoblastic cells by stimulation of BMP production.

The phosphatidylinositol 3'-kinase (PI3K)-AKT (protein kinase B) signaling pathway is activated by growth factors and extracellular signals. It regulates fundamental cellular functions such as transcription, translation, proliferation, growth, and survival (36). One important function of activated PI3K in cells is the inhibition of apoptosis (37). AKT is a prime candidate for mediating these PI3K-dependent cell survival responses. AKT plays a role as an anti-apoptotic factor in many different cell death paradigms, including the withdrawal of extracellular signaling factors, oxidative and osmotic stress, irradiation, and the treatment of cells with chemotherapeutic drugs and ischemic shock (38). The various flavonoids exert a protective effect against antimycin A (an inhibitor of mitochondrial electron transport)-induced oxidative cell damage via the activation of PI3K and/or AKT in MC3T3-E1 osteoblastic cells (39-41). Previously, it was demonstrated that the flavonoid glabridin activated the reducing sugar-induced decreased expression of PI3K and AKT2 genes, which are key regulators of survival-related signaling pathways (23). In the present study, apigenin also induced the activation of PI3K and protein kinase $\mathrm{B} 2$ (AKT2) inhibited by $\mathrm{H}_{2} \mathrm{O}_{2}$ (Fig. 6). Since these signaling are involved in cell survival pathways, apigenin may be cytoprotective for osteoblastic cells during oxidative stress responses.

The extracellular signal-related kinase (ERK) plays a role in the signaling pathway in osteoblastic cells and activation of ERK was found to enhance osteoblast gene expression $(42,43)$. Lee et al (44) reported that the Typha angustata pollen extract attenuates the $\mathrm{H}_{2} \mathrm{O}_{2}$-induced reduction of differentiation, which is associated with increased activation of protein kinase $\mathrm{C}$ and ERK. Zinc was found to inhibit $\mathrm{H}_{2} \mathrm{O}_{2}$-induced apoptosis in osteoblastic cells by activation of the ERK pathway (45). Conflicting results were reported on the role of ERK. ERK and ERK-dependent nuclear factor- $\kappa \mathrm{B}(\mathrm{NF}-\kappa \mathrm{B})$ activation is required for the oxidative stress-induced inhibition of osteoblastic differentiation in rabbit bone marrow stromal cells and calvarial osteoblasts (46). In the present study, $\mathrm{H}_{2} \mathrm{O}_{2}$ inhibited 


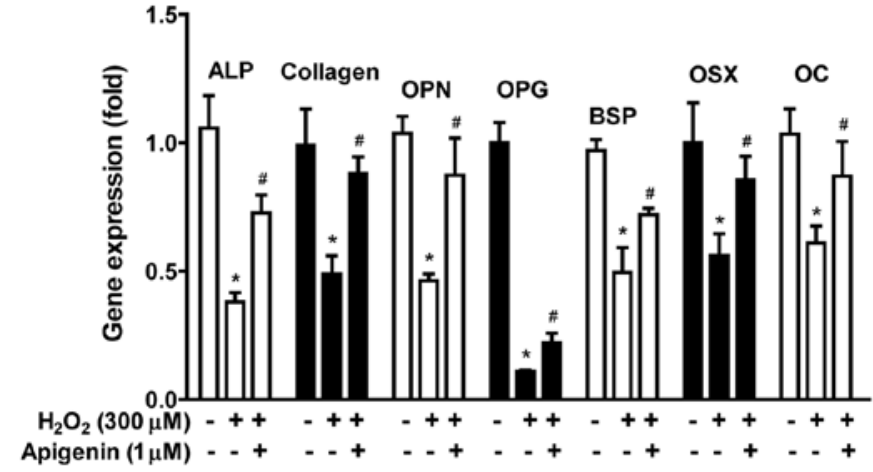

Figure 4. Effect of apigenin on the hydrogen peroxide $\left(\mathrm{H}_{2} \mathrm{O}_{2}\right)$-induced gene expression involved in osteoblastic differentiation. Total RNA was extracted from osteoblastic cells and the mRNA levels for alkaline phosphatase (ALP), collagen, osteopontin (OPN), osteoprotegerin (OPG), bone sialoprotein (BSP), osterix (OSX) and osteocalcin (OC) were assessed by RT-PCR as described in 'Materials and methods'. The data are expressed as the means \pm standard deviation (SD) of three independent determinations. ${ }^{*} \mathrm{P}<0.05$ vs. untreated control, ${ }^{\#} \mathrm{p}<0.05$ vs. $\mathrm{H}_{2} \mathrm{O}_{2}$-treated cells.

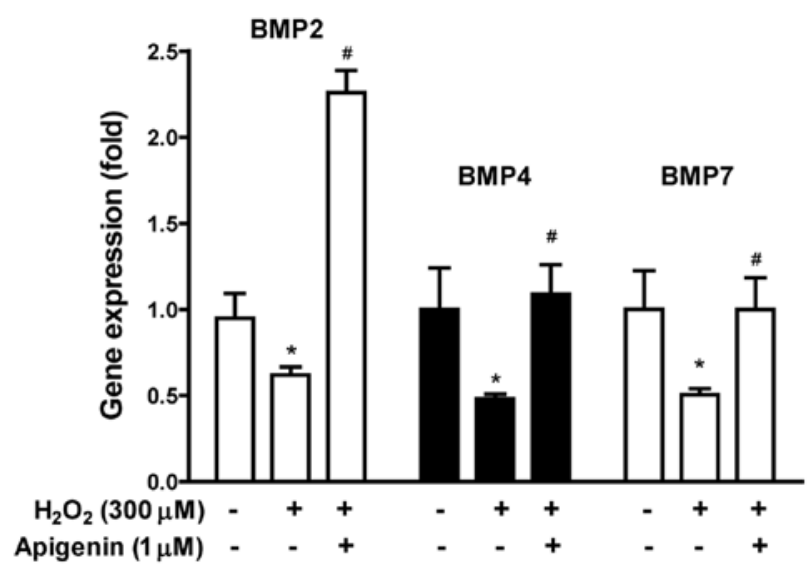

Figure 5. Effect of apigenin on hydrogen peroxide $\left(\mathrm{H}_{2} \mathrm{O}_{2}\right)$-induced bone morphogenetic proteins (BMPs) gene expression in osteoblastic cells. Total RNA was extracted from osteoblastic cells and the mRNA levels for BMP2, BMP4 and BMP7 were assessed by RT-PCR as described in 'Materials and methods'. The data are expressed as the means \pm standard deviation (SD) of three independent determinations. ${ }^{*} \mathrm{P}<0.05$ vs. untreated control, ${ }^{\#} \mathrm{p}<0.05$ vs. $\mathrm{H}_{2} \mathrm{O}_{2}$-treated cells.

the gene expression of ERK2 but not ERK1 and ERK5. However, apigenin induced the activation of ERK1,ERK2 and ERK5 (Fig. 6). These data suggest that the protection of cell damage by apigenin is associated with the increased activation of ERK.

ROS are known to be key mediators in the NF- $\mathrm{kB}$ activation process (47). Aluminum induced osteoblast apoptosis by activating the oxidative stress-mediated c-Jun N-terminal kinase (JNK) pathway, which caused cell injuries and reduced the number and function of osteoblastic cells (48). By contrast, there were no changes in the expression of NF- $\kappa \mathrm{B}$ and JNK genes exposed to $\mathrm{H}_{2} \mathrm{O}_{2}$ in the present study (Fig. 6). An increase in oxidative stress may not be required for activation of these gene expressions. Additionally, it is possible that the magnitude and/or duration of oxidative stress may be insufficient to determine the activation of these gene expressions.

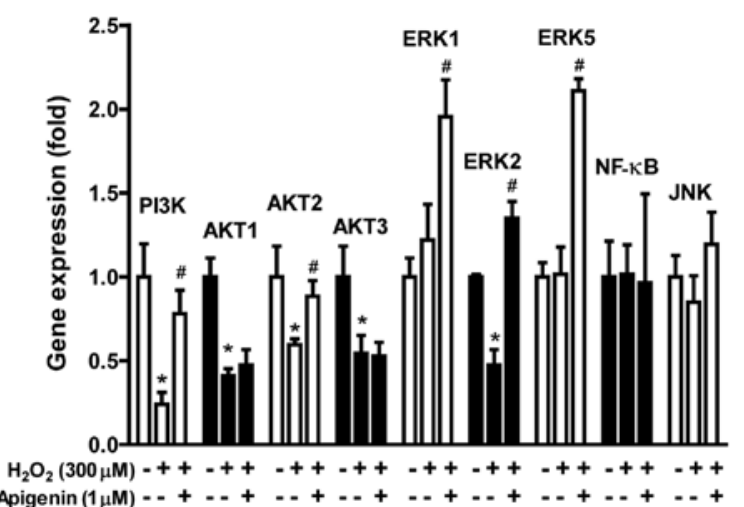

Figure 6. Effect of apigenin on hydrogen peroxide $\left(\mathrm{H}_{2} \mathrm{O}_{2}\right)$-induced gene expression involved in osteoblastic survival signaling pathway. Total RNA was extracted from osteoblastic cells and the mRNA levels for phosphatidylinositol 3'-kinase (PI3K), protein kinase B2 (AKT), extracellular signal-related kinase (ERK), nuclear factor- $\mathrm{kB}(\mathrm{NF}-\mathrm{\kappa B})$ and c-Jun N-terminal kinase (JNK) were assessed by RT-PCR as described in 'Materials and methods'. The data are expressed as the means \pm standard deviation (SD) of three independent determinations. ${ }^{*} \mathrm{P}<0.05$ vs. untreated control, ${ }^{\#} \mathrm{p}<0.05$ vs. $\mathrm{H}_{2} \mathrm{O}_{2}$-treated cells.

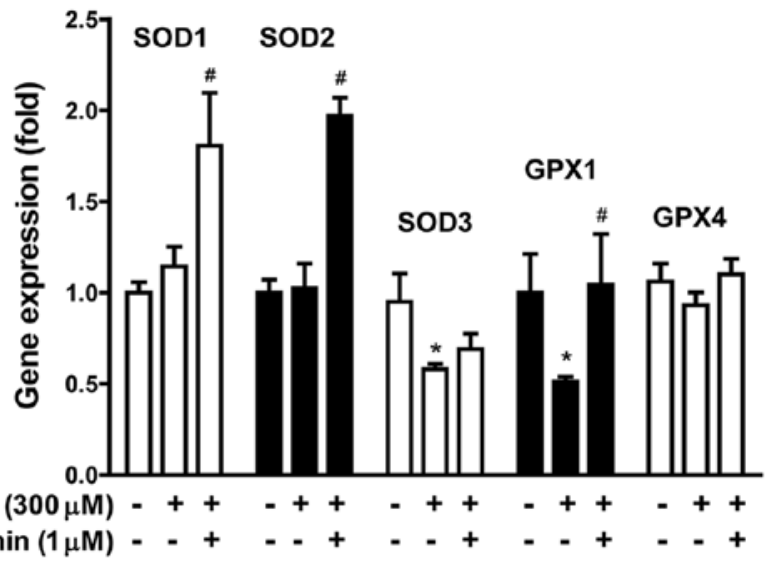

Figure 7. Effect of apigenin on hydrogen peroxide $\left(\mathrm{H}_{2} \mathrm{O}_{2}\right)$-induced gene expression involved in osteoblastic anti-oxidant enzymes. Total RNA was extracted from osteoblastic cells and the mRNA levels for superoxide dismutase (SOD)1, SOD2, SOD3, glutathione peroxidase (GPx) 1 and GPx4 were assessed by real-time polymerase chain reaction (RT-PCR) as described in materials and methods. The data are expressed as the means \pm standard deviation (SD) of three independent determinations. " $\mathrm{P}<0.05$ vs. untreated control, ${ }^{\#} \mathrm{p}<0.05$ vs. $\mathrm{H}_{2} \mathrm{O}_{2}$-treated cells.

Excess ROS should be immediately eliminated from the cell by the antioxidant defense mechanisms. Cellular antioxidant enzymes and other redox molecules serve to counterbalance ROS generated in the cell. Superoxide dismutase (SOD), which catalyzes the dismutation of the superoxide anion into $\mathrm{H}_{2} \mathrm{O}_{2}$ and molecular oxygen, is one of the most important antioxidant enzymes (49). These enzymes are classified into three groups: CuZn-SOD (SOD1), located in the cytoplasm; Mn-SOD (SOD2) in the mitochondria; and EC-SOD (SOD3), which is located on cell surfaces and in the extracellular matrix. Glutathione peroxidase (GPx) catalyzes the reduction of hydroperoxides, including $\mathrm{H}_{2} \mathrm{O}_{2}$ by reduced glutathione and functions to protect the cell from oxidative damage. GPx 1 is the most abundant version, found in the cytoplasm of almost all mammalian tissues, whose preferred substrate is $\mathrm{H}_{2} \mathrm{O}_{2}$. GPx4 has a high preference for lipid hydroperoxides. It has been reported $(23,50,51)$ 
that various flavonoids increased the activity of antioxidant enzymes in osteoblastic cells. Quercetin diminishes oxidative human osteoblastic cell damage by scavenging the radicals and by upregulating the expression of heme oxygenase-1 (HO-1) and SOD-1 exposed to cigarette smoke medium (50). The flavonoids from persimmon results in a significant decrease in the level of ROS and malondialdehyde (MDA), while increasing the activity of catalase, SOD and GPx in MC3T3-E1 cells (51). In a recent study it was demonstrated that the flavonoid glabridin also upregulated the gene expression of antioxidant enzymes, SOD and GPx4, which were inhibited by the highly reducing sugar (23). Findings of another study demonstrated that the intracellular redox imbalance caused by SOD1 deficiency plays a pivotal role in the development and progression of bone fragility both in vitro and in vivo (52). In this study, in addition to the biochemical aspects of oxidative stress, the gene expression of antioxidative enzymes was investigated. $\mathrm{H}_{2} \mathrm{O}_{2}$ exerted an inhibitory effect on the gene expression of SOD3 and GPx1 but not SOD1, SOD2 and GPx4. However, when osteoblasts were treated with apigenin in the presence of $300 \mu \mathrm{M} \mathrm{H}_{2} \mathrm{O}_{2}$, significant increases in the gene expression of SOD1, SOD2 and GPx1, but not SOD3, GPx4 were observed (Fig. 7).

In contrast to the antioxidant effects of apigenin in osteoblastic cells as observed in this study, apigenin has also been shown to confer anticancer effects in other cell types. The anticancer mechanism of apigenin and the implications of glucose transporter-1 (GLUT-1) expression in head and neck cancers have been reported (53). The anticancer potential of apigenin has been reported in an oral squamous cell carcinoma cell line, suggesting that it is a promising chemopreventive agent (54). Thus, apigenin appears to have different biological effects on different cell types. The mechanism by which apigenin exerts these cell-specific effects remains to be clarified.

In conclusion, this study demonstrates that apigenin attenuates oxidative-induced cell damage in MC3T3-E1 osteoblastic cells due to its antioxidant activity and improvement of differentiation function, which may promote bone recovery oxidative stress-related bone metabolism.

\section{Acknowledgements}

This study was supported by the research grant of Cheongju University in 2013.

\section{References}

1. Da Silva FM, Marques A and Chaveiro A: Reactive oxygen species: a double-edged sword in reproduction. Open Vet Sci J 4: 127-133, 2010

2. Maggio D, Barabani M, Pierandrei M, Polidori MC, Catani M, Mecocci P, Senin U, Pacifici R and Cherubini A: Marked decrease in plasma antioxidants in aged osteoporotic women: results of a cross-sectional study. J Clin Endocrinol Metab 88: $1523-1527,2003$.

3. Basu S, Michaëlsson K, Olofsson H, Johansson S and Melhus H: Association between oxidative stress and bone mineral density. Biochem Biophys Res Commun 288: 275-279, 2001.

4. Ozgocmen S, Kaya H, Fadillioglu E, Aydogan R and Yilmaz Z: Role of antioxidant systems, lipid peroxidation, and nitric oxide in postmenopausal osteoporosis. Mol Cell Biochem 295: 45-52, 2007.

5. Manolagas SC: De-fense! de-fense! de-fense: scavenging $\mathrm{H}_{2} \mathrm{O}_{2}$ while making cholesterol. Endocrinology 149: 3264-3266, 2008.
6. Lee DH, Lim BS, Lee YK and Yang HC: Effects of hydrogen peroxide $\left(\mathrm{H}_{2} \mathrm{O}_{2}\right)$ on alkaline phosphatase activity and matrix mineralization of odontoblast and osteoblast cell lines. Cell Biol Toxicol 22: 39-46, 2006.

7. Mody N, Parhami F, Sarafian TA and Demer LL: Oxidative stress modulates osteoblastic differentiation of vascular and bone cells. Free Radic Biol Med 31: 509-519, 2001.

8. Mogi M, Kinpara K, Kondo A and Togari A: Involvement of nitric oxide and biopterin in proinflammatory cytokine-induced apoptotic cell death in mouse osteoblastic cell line MC3T3-E1. Biochem Pharmacol 58: 649-654, 1999.

9. Choi EM, Kim GH and Lee YS: Protective effects of dehydrocostus lactone against hydrogen peroxide-induced dysfunction and oxidative stress in osteoblastic MC3T3-E1 cells. Toxicol In Vitro 23: 862-867, 2009.

10. Xiao Y, Cui J, Shi Y and Le G: Alpha-lipoic acid protects against hydrogen peroxide-induced oxidative stress in MC3T3-E1 osteoblast-like cells. J Funct Foods 4: 642-649, 2012.

11. Fatokun AA, Stone TW and Smith RA: Hydrogen peroxideinduced oxidative stress in MC3T3-E1 cells: the effects of glutamate and protection by purines. Bone 39: 542-551, 2006.

12. Weinstein RS, Jilka RL, Parfitt AM and Manolagas SC: Inhibition of osteoblastogenesis and promotion of apoptosis of osteoblasts end osteocytes by glucocorticoids. Potential mechanisms of their deleterious effects on bone. J Clin Invest 102: 274-282, 1998.

13. Havsteen BH: The biochemistry and medical significance of the flavonoids. Pharmacol Ther 96: 67-202, 2002.

14. Fernandez de Simon B, Perez-Ilzarbe J, Hernandez T, Gomez-Cordoves C and Estrella I: Importance of phenolic compounds for the characterization of fruit juices. J Agric Food Chem 40: 1531-1535, 1992.

15. Chan LP, Chou TH, Ding HY, Chen PR, Chiang FY, Kuo PL and Liang $\mathrm{CH}$ : Apigenin induces apoptosis via tumor necrosis factor receptor and-Bcl-2-mediated pathway and enhances susceptibility of head and neck squamous cell carcinoma to 5-fluorouracil and cisplatin. Biochim Biophys Acta 1820: 1081-1091, 2012.

16. Mafuvadze B, Liang Y, Besch-Williford C, Zhang X and Hyder SM: Apigenin induces apoptosis and blocks growth of medroxyprogesterone acetate-dependent BT-474 xenograft tumors. Horm Cancer 3: 160-171, 2012.

17. Nicholas C, Batra S, Vargo MA, Voss OH, Gavrilin MA, Wewers MD, Guttridge DC, Grotewold E and Doseff AI: Apigenin blocks lipopolysaccharide-induced lethality in vivo and proinflammatory cytokines expression by inactivating NF- $\kappa \mathrm{B}$ through the suppression of p65 phosphorylation. J Immunol 179: 7121-7127, 2007.

18. Landolfi R, Mower RL and Steiner M: Modification of platelet function and arachidonic acid metabolism by bioflavonoids. Structure-activity relations. Biochem Pharmacol 33: 1525-1530, 1984.

19. Henkel KM, Frondorf K, Gonzalez-Mejia ME, Doseff AL and Gomez-Cambronero J: IL-8-induced neutrophil chemotaxis is mediated by Janus kinase 3 (JAK3). FEBS Lett 585: 159-166, 2011.

20. Choi EM: Apigenin increases osteoblastic differentiation and inhibits tumor necrosis factor- $\alpha$-induced production of interleukin- 6 and nitric oxide in osteoblastic MC3T3-E1 cells. Pharmazie 62: 216-220, 2007

21. Kanno S, Anuradha CD and Hirano S: Localization of zinc after in vitro mineralization in osteoblastic cells. Biol Trace Elem Res 83: 39-47, 2001.

22. Suh KS, Chon S, Oh S, Kim SW, Kim JW, Kim YS and Woo JT: Prooxidative effects of green tea polyphenol (-)-epigallocatechin-3-gallate on the HIT-T15 pancreatic beta cell line. Cell Biol Toxicol 26: 189-199, 2010.

23. Kim HS, Suh KS, Ko A, Sul D, Choi D, Lee SK and Jung WW: The flavonoid glabridin attenuates 2-deoxy-D-ribose-induced oxidative damage and cellular dysfunction in MC3T3-E1 osteoblastic cells. Int J Mol Med 31: 243-251, 2013.

24. Szilágyi G, Simon L, Koska P, Telek G and Nagy Z: Visualization of mitochondrial membrane potential and reactive oxygen species via double staining. Neurosci Lett 399: 206-209, 2006.

25. Salido M, Gonzalez JL and Vilches J: Loss of mitochondrial membrane potential is inhibited by bombesin in etoposideinduced apoptosis in PC-3 prostate carcinoma cells. Mol Cancer Ther 6: 1292-1299, 2007.

26. Sudo H, Kodama HA, Amagai Y, Yamamoto S and Kasai S: In vitro differentiation and calcification in a new clonal osteogenic cell line derived from newborn mouse calvaria. J Cell Biol 96: 191-198, 1983. 
27. Bellows CG, Aubin JE and Heersche JN: Initiation and progression of mineralization of bone nodules formed in vitro: the role of alkaline phosphatase and organic phosphate. Bone Miner 14: 27-40, 1991.

28. Domon S, Shimokawa H, Yamaguchi S and Soma K: Temporal and spatial mRNA expression of bone sialoprotein and type I collagen during rodent tooth movement. Eur J Orthod 23: 339-348, 2001

29. Yang L, Takai H, Utsunomiya T, Li X, Li Z, Wang Z, Wang S, Sasaki Y, Yamamoto H and Ogata Y: Kaempferol stimulates bone sialoprotein gene transcription and new bone formation. J Cell Biochem 110: 1342-1355, 2010

30. Khosla S: Minireview: the OPG/RANKL/RANK system. Endocrinology 142: 5050-5055, 2001.

31. Wade-Gueye NM, Boudiffa M, Vanden-Bossche A, Laroche N, Aubin JE, Vico L, Lafage-Proust MH and Malaval L: Absence of bone sialoprotein (BSP) impairs primary bone formation and resorption: the marrow ablation model under PTH challenge. Bone 50: 1064-1073, 2012

32. Cao Y, Zhou Z, de Crombrugghe B, Nakashima K, Guan H, Duan X, Jia SF and Kleinerman ES: Osterix, a transcription factor for osteoblast differentiation, mediates antitumor activity in murine osteosarcoma. Cancer Res 65: 1124-1128, 2005.

33. Zhou X, Zhang Z, Feng JQ, Dusevich VM, Sinha K, Zhang H, Darnay BG and de Crombrugghe B: Multiple functions of Osterix are required for bone growth and homeostasis in postnatal mice. Proc Natl Acad Sci USA 107: 12919-12924, 2010.

34. Takuwa Y, Ohse C, Wang EA, Wozney JM and Yamashita K: Bone morphogenetic protein-2 stimulates alkaline phosphatase activity and collagen synthesis in cultured osteoblastic cells, MC3T3-E1. Biochem Biophys Res Commun 174: 96-101, 1991.

35. Nakase T, Takaoka K, Masuhara K, Shimizu K, Yoshikawa $H$ and Ochi T: Interleukin- $1 \beta$ enhances and tumor necrosis factor- $\alpha$ inhibits bone morphogenetic protein-2-induced alkaline phosphatase activity in MC3T3-E1 osteoblastic cells. Bone 21: 17-21, 1997.

36. Vivanco I and Sawyers CL: The phosphatidylinositol 3-kinase AKT pathway in human cancer. Nat Rev Cancer 2: 489-501, 2002.

37. Yao R and Cooper GM: Requirement for phosphatidylinositol-3 kinase in the prevention of apoptosis by nerve growth factor. Science 267: 2003-2006, 1995.

38. Franke TF, Kaplan DR and Cantley LC: PI3K: downstream AKTion blocks apoptosis. Cell 88: 435-437, 1997.

39. Choi EM: Deoxyactein isolated from cimicifuga racemosa protects osteoblastic MC3T3-E1 cells against antimycin A-induced cytotoxicity. J Appl Toxicol 33: 488-494, 2013

40. Choi EM and Lee YS: Protective effect of apocynin on antimycin A-induced cell damage in osteoblastic MC3T3-E1 cells. J Appl Toxicol 32: 714-721, 2012.

41. Choi EM: Honokiol protects osteoblastic MC3T3-E1 cells against antimycin A-induced cytotoxicity. Inflamm Res 60:1005-1012, 2011.
42. Kim HJ, Kim JH, Bae SC, Choi JY, Kim HJ and Ryoo HM: The protein kinase $C$ pathway plays a central role in the fibroblast growth factor-stimulated expression and transactivation activity of Runx2. J Biol Chem 278: 319-326, 2003.

43. Xiao G, Jiang D, Gopalakrishnan R and Franceschi RT: Fibroblast growth factor 2 induction of the osteocalcin gene requires MAPK activity and phosphorylation of the osteoblast transcription factor, Cbfa1 / Runx2. J Biol Chem 277: 36181-36187, 2002.

44. Lee YS and Choi EM: Effect of pollen from Typha angustata on hydrogen peroxide induced toxicity in osteoblastic MC3T3-E1 cells. J Oral Pathol Med 41: 171-177, 2012.

45. Liang D, Yang M, Guo B, Cao J, Yang L, Guo X, Li Y and Gao Z: Zinc inhibits $\mathrm{H}_{2} \mathrm{O}_{2}$-induced MC3T3-E1 cells apoptosis via MAPK and PI3K/AKT pathways. Biol Trace Elem Res 148: 420-429, 2012.

46. Bai XC, Lu D, Bai J, Zheng H, Ke ZY, Li XM and Luo SQ: Oxidative stress inhibits osteoblastic differentiation of bone cells by ERK and NF- $\kappa$ B. Biochem Biophys Res Commun 314: 197-207, 2004

47. Schmidt KN, Amstad P, Cerutti P and Baeuerle PA: Identification of hydrogen peroxide as the relevant messenger in the activation pathway of transcription factor NF- $\kappa$ B. Adv Exp Med Biol 387: 63-68, 1996.

48. Li X, Han Y, Guan Y,Zhang L, Bai C and Li Y: Aluminum induces osteoblast apoptosis through the oxidative stress-mediated JNK signaling pathway. Biol Trace Elem Res 150: 502-508, 2012.

49. Zelko IN, Mariani TJ and Folz RJ: Superoxide dismutase multigene family: a comparison of the CuZn-SOD (SOD1), Mn-SOD (SOD2), and EC-SOD (SOD3) gene structures, evolution, and expression. Free Radic Biol Med 33: 337-349, 2002.

50. Braun KF, Ehnert S, Freude T,Egaña JT, Schenck TL, Buchholz A, Schmitt A, Siebenlist S, Schyschka L, Neumaier M, Stöckle U and Nussler AK: Quercetin protects primary human osteoblasts exposed to cigarette smoke through activation of the antioxidative enzymes HO-1 and SOD-1. ScientificWorldJournal 11: 2348-2357, 2011.

51. Sun L, Zhang J, Lu X, Zhang L and Zhang Y: Evaluation to the antioxidant activity of total flavonoids extract from persimmon (Diospyros kaki L.) leaves. Food Chem Toxicol 49: 2689-2696, 2011.

52. Nojiri H, Saita Y, Morikawa D, Kobayashi K, Tsuda C, Miyazaki T, Saito M, Marumo K, Yonezawa I, Kaneko K, Shirasawa T and Shimizu T: Cytoplasmic superoxide causes bone fragility owing to low-turnover osteoporosis and impaired collagen cross-linking. J Bone Miner Res 26: 2682-2694, 2011.

53. Bao YY, Zhou SH, Fan J and Wang QY: Anticancer mechanism of apigenin and the implications of GLUT-1 expression in head and neck cancers. Future Oncol 9: 1353-1364, 2013.

54. Maggioni D, Garavello W, Rigolio R, Pignataro L, Gaini R and Nicolini G: Apigenin impairs oral squamous cell carcinoma growth in vitro inducing cell cycle arrest and apoptosis. Int J Oncol 43: 1675-1682, 2013. 